\title{
A Study on Speaking Anxiety of English Education Study Program Students at the University of Palangka Raya
}

\author{
Yoskapela $^{1^{*}}$, Susanty $^{2}$, Bahing $^{3}$, Ristati $^{4}$ \\ 1, 2, 3, ${ }^{4}$ English Education Study Program, Teacher Training and Education Faculty, University of Palangka Raya
}

\begin{abstract}
English-speaking anxiety is a specific phenomenon in the context of English language learning which has debilitating consequences on EFL learners' speaking skills if the condition is severe. Focusing on this issue, this study was intended to describe the levels of speaking anxiety of English Education Study Program's fourth-semester students who are taking Advanced EnglishSpeaking Course at University of Palangka Raya. To obtain the objective, the data were collected through observation, questionnaire, and documentation. The result of data analysis revealed that the participants mostly experience a moderate speaking anxiety level because their average number of speaking anxiety signs as observed is 2, and their average FLSAS score from the questionnaire is 53.83. As evidenced by the data distribution, 15 participants (42.9\%) have a moderate level, followed by 14 participants $(40.0 \%)$ who have a low level and 6 participants $(17.1 \%)$ who have a high level. Furthermore, it can be inferred that the higher the level of speaking anxiety is, the lower the speaking score they have. Concerning this result, it is suggested that the lecturers should formulate teaching strategies to help students reduce their speaking anxiety. Likewise, students should be active in finding ways to alleviate their speaking anxiety level.
\end{abstract}

Keywords: EFL Speaking Anxiety, EFL Speaking Anxiety Levels

\section{INTRODUCTION}

Speaking ability is mainly perceived as the priority for learners of Foreign Language (FL). When learners are fluent in speaking, they are considered successful in learning FL. That is because speaking involves other components, such as grammar, vocabulary, pronunciation, topical knowledge and listening skills. If they are able to integrate those complexities in their oral speech according to the context, they can achieve the ultimate goal of learning FL, which is communication (Burns, 2017:243). Although speaking is very essential in leading to successful FL learning, many learners hardly master it as speaking performance is influenced by a number of factors, and one of them is FL speaking anxiety.

According to Brown (as cited in Mahmoodzadeh 2012:467), FL speaking anxiety is the feeling of uneasiness, discouragement, self-uncertainty, or fear that is apparent when speaking the target language. Pertaining to this issue, many FL learners experience speaking anxiety during the learning process in a language classroom. The reason is because the only environment for them to learn and practice speaking in FL intensely is in the FL classroom (Galajda, 2017:49).

\footnotetext{
*Corresponding author: yoskapela@yahoo.com

To cite this article: Yoskapela, Susanty, Bahing, \& Ristati (2022). A Study on Speaking Anxiety of English Education Study Program Students at the University of Palangka Raya. Ebony --- Journal of English Language Teaching, Linguistics, and Literature, 2 (1) 2022, pp. 14--27.
} 
In English as a Foreign Language (EFL) classroom context, English is used by students as an instructional language. For example, they use English to deliver an oral presentation or participate in classroom discussions. Consequently, this situation can naturally provoke their anxiety in speaking (Young as cited in Gass 2013:143). By having anxiety, students tend to be discouraged to speak in the classroom as the anxiety signs are apparent in their behavioral reactions during speaking (Gkonou, Dewaele, \& Daubney, 2017:54). For instance, when students are anxious during speaking performances, they tend to go blank, use constant speech fillers in the middle of speech, speak too fast or too slow, make grammatical mistakes or make unnecessary body movements repetitively (Suleimenova, 2013:1861-1862).

Considering the above circumstances, it is foreseeable that many EFL students perceive speaking anxiety as the cause of their unsatisfactory speaking performances. However, it must be understood that anxiety in speaking does not only serve a weakening effect to speaking performance. In fact, a low level of anxiety is normal and needed to create motivation and awareness in speaking performance. Correspondingly, it provides a facilitating effect to speaking skills improvement and achievement. On the other hand, if anxiety is at a high level, it contributes to the deterioration of speaking skills, poor speaking achievement, and unwillingness to perform speaking in class.

Given that speaking anxiety seems to serves either a facilitating or debilitating effect depending on the level of anxiety itself, several researchers from various contexts attempted to find out the levels of speaking anxiety in the EFL classroom. (e.g. Agudo, 2013; Öztürk and Gürbüz, 2014; Çagatay, 2015). Their explorations led to the results that students experience varying speaking anxiety levels. However, it could be interpreted that the higher the level is, the more debilitating it affects the speaking performances.

Relying on the relevant works of literature above, the researcher takes the initiative to seek more evidence on this phenomenon from the context of English Education Study Program at University of Palangka Raya. Based on the preliminary study conducted in the Advanced English-Speaking class, students confessed that they are nervous when they do an oral presentation or when they have to speak without preparation. They also mentioned that they sometimes avoid speaking in front of the classroom because being nervous while speaking makes them not physically well. As their responses showed the indications of English-speaking anxiety, it was possible that they might experience certain levels of speaking anxiety. Therefore, there was an urgent need to explore this issue by describing the levels of their English-speaking anxiety. In the light of this aim, the researcher intended to address how their English-speaking anxiety levels affect their speaking performances.

\section{METHOD}

As this study focused on describing the English-speaking anxiety levels, the descriptivequalitative design was applied. In conducting this study, the researcher decided for it to take place during Advanced English-Speaking course in English Education Study Program at University of Palangka Raya in the academic year 2020/2021. 35 students from group B of Advanced English-Speaking course were recruited as the participants of this study. 
Furthermore, observation, questionnaire, and documentation were utilized because having data which have been collected through different techniques provide more reliable results and reduce the potential biases. Correspondingly, three different instruments were used. The first set of data was collected using the observation checklist. The second set of data was sought using the adapted FLSAS questionnaire distributed to the participants. The third set of data was collected through the document sheet of the participants' speaking scores given by the lecturer. After collecting the data, the analysis was done. First, to analyze the data from observation, the researcher compiled the filled-out observation checklists, classified participants who fell into the same sign(s) of speaking anxiety into one row of table, and interpreted the data. Second, to analyze the data from FLSAS questionnaire, the researcher conducted several steps, i.e. 1) using descriptive statistics tool in SPSS Software to calculate the total FLSAS score; 2) determining the level of each participant's speaking anxiety by consulting the total FLSAS score to the scale of FL speaking anxiety level (a total score in the range of $17-50$ presents a low level, a total score in the range of 51-68 presents a moderate level, and a total score in the range of $69-85$ presents a high level); 3) and interpreting the data. Finally, to analyze the data from speaking score document, the researcher compared their latest speaking scores with their speaking anxiety levels and then made an interpretation of the data.

\section{RESULTS}

From an analysis of the three data sets, the results were obtained to address the objective. The results of the analysis of the three data sets are presented as follows.

\section{The Result from the Observation Data Analysis}

To describe the speaking anxiety levels based on the observation, the researcher counted any speaking anxiety sign(s) identified from their speaking performances, such as going blank (i.e. making pauses), using speech fillers, making grammatical mistakes, making unnecessary body movements, speaking too fast, speaking too slow, or stuttering. From the analysis of the data in the observation checklists, several findings are highlighted. First, the researcher found that 14 participants are the least anxious in speaking. They consist of 9 participants who did not show any sign of speaking anxiety, and 5 participants who exhibited only one sign that yet appeared slightly in their speaking performances. As the speaking anxiety sign barely appeared in their speaking performances, they had the most fluent speaking compared to other participants. In addition, the researcher discovered that 15 participants are moderately anxious. They consist of 11 participants who seemed to show two signs of speaking anxiety, and 4 participants who demonstrated three signs of speaking anxiety. Since the number of speaking anxiety signs in their performances is in the range of 2 to 3, it was found that their speaking anxiety signs were somewhat inhibiting to their speaking fluency. Nonetheless, they still managed to complete their speech in a coherent manner. Furthermore, it was discovered that 6 participants are the most anxious in speaking. 4 of them displayed four speaking anxiety signs, and 2 of them showed five speaking anxiety signs. In total, these 6 participants had the most signs in their speaking performances compared to others. Consequently, four to five speaking anxiety signs appearing altogether 
were impactful to harm their speaking performances. It was noted that their speaking anxiety signs made them be not fluent, not clear and incomprehensible in their speech.

\section{The Result from the Adapted FLSAS Questionnaire Data Analysis}

To describe the levels of English-speaking anxiety based on the participants' perceptions toward the three sources of speaking anxiety (communication apprehension, fear of negative evaluation and test-anxiety), the data from 5-graded Likert scale adapted from Öztürk \& Gürbüz (2014) were consulted to the scale of FL speaking anxiety level. A total score from 17 to 50 shows a low level of English-speaking anxiety, a total score from 51 to 68 presents a moderate level of English-speaking anxiety, and a total score of more than 69 demonstrates a high level of English-speaking anxiety. The result is presented in Table 1, Table 2 and Table 3 below.

Table 1. Participants'Speaking Anxiety from FLSAS Questionnaire

\begin{tabular}{|c|c|c|c|}
\hline No. & Participant's Code & Total FLSAS Score & Level of Speaking Anxiety \\
\hline 1 & $\mathrm{P} 1$ & 63 & Moderate \\
\hline 2 & $\mathrm{P} 2$ & 49 & Low \\
\hline 3 & $\mathrm{P} 3$ & 61 & Moderate \\
\hline 4 & $\mathrm{P} 4$ & 72 & High \\
\hline 5 & P5 & 64 & Moderate \\
\hline 6 & P6 & 48 & Low \\
\hline 7 & $\mathrm{P7}$ & 70 & High \\
\hline 8 & P8 & 49 & Low \\
\hline 9 & P9 & 33 & Low \\
\hline 10 & $\mathrm{P} 10$ & 56 & Moderate \\
\hline 11 & P11 & 61 & Moderate \\
\hline 12 & $\mathrm{P} 12$ & 71 & High \\
\hline 13 & $\mathrm{P} 13$ & 54 & Moderate \\
\hline 14 & P14 & 47 & Low \\
\hline 15 & $\mathrm{P} 15$ & 50 & Low \\
\hline 16 & $\mathrm{P} 16$ & 34 & Low \\
\hline 17 & P17 & 69 & High \\
\hline 18 & P18 & 35 & Low \\
\hline 19 & P19 & 63 & Moderate \\
\hline 20 & $\mathrm{P} 20$ & 50 & Low \\
\hline 21 & $\mathrm{P} 21$ & 18 & Low \\
\hline 22 & $\mathrm{P} 22$ & 53 & Moderate \\
\hline 23 & $\mathrm{P} 23$ & 64 & Moderate \\
\hline 24 & P24 & 60 & Moderate \\
\hline 25 & $\mathrm{P} 25$ & 30 & Low \\
\hline 26 & P26 & 78 & High \\
\hline 27 & P27 & 39 & Low \\
\hline 28 & $\mathrm{P} 28$ & 32 & Low \\
\hline 29 & $\mathrm{P} 29$ & 33 & Low \\
\hline 30 & P30 & 64 & Moderate \\
\hline 31 & P31 & 54 & Moderate \\
\hline 32 & P32 & 54 & Moderate \\
\hline 33 & P33 & 66 & Moderate \\
\hline 34 & P34 & 84 & High \\
\hline
\end{tabular}




\begin{tabular}{llll}
\hline 35 & P35 & 56 & Moderate \\
\hline
\end{tabular}

Table 2. The Average Level of Participants' Speaking Anxiety

\section{Descriptive Statistics}

\begin{tabular}{lccccc}
\hline & N & Minimum & Maximum & Mean & $\begin{array}{c}\text { Std. } \\
\text { Deviation }\end{array}$ \\
\hline Total FLSAS & 35 & 18 & 84 & $\mathbf{5 3 . 8 3}$ & 15.058 \\
\hline Valid N (listwise) & 35 & & & & \\
\hline The Average Level & & \multicolumn{3}{c}{ Moderate } \\
\hline
\end{tabular}

Table 3. The Percentages and Frequency of Participants' Speaking Anxiety Levels

\begin{tabular}{|c|c|c|c|c|}
\hline \multicolumn{5}{|c|}{ Data Distribution } \\
\hline & FLSA Levels & & Frequency & Valid Percent \\
\hline \multirow[t]{4}{*}{ Valid } & & Low & 14 & $40.0 \%$ \\
\hline & & Moderate & 15 & $42.9 \%$ \\
\hline & & High & 6 & $17.1 \%$ \\
\hline & & Total & 35 & $100.0 \%$ \\
\hline
\end{tabular}

Based on the tables above, it can be inferred that participants experience low, moderate to high levels of speaking anxiety. It was found that 14 of them $(40.0 \%)$ demonstrate a low speaking anxiety level. Furthermore, 15 of them (42.9\%) have a moderate speaking anxiety level. Lastly, 6 of them (17.1\%) have a high speaking anxiety level. Although the participants experience different levels of English-speaking anxiety, it was indicated from the descriptive statistics analysis that participants generally perceive a moderate level of speaking anxiety because the mean of all participants' FLSAS is 53.83.

\section{The Result from the Speaking Scores Document Analysis}

To describe the speaking anxiety levels' impacts on the speaking achievements of the participants, the researcher compared their latest speaking scores as received from the lecturer with the speaking anxiety levels as found in the observation and questionnaire analysis.

Table 4. The Comparison between Speaking Score and Speaking Anxiety Level of Participants

\begin{tabular}{cccl}
\hline No & Participant & Speaking Score & Speaking Anxiety Level \\
\hline 1 & P1 & 79 & Moderate \\
\hline 2 & P2 & 83 & Low \\
\hline 3 & P3 & 79 & Moderate \\
\hline 4 & P4 & 76 & High \\
\hline 5 & P5 & 80 & Moderate \\
\hline 6 & P6 & 84 & Low \\
\hline 7 & P7 & 77 & High \\
\hline 8 & P8 & 83 & Low \\
\hline 9 & P9 & 84 & Low \\
\hline
\end{tabular}




\begin{tabular}{|c|c|c|c|}
\hline 10 & $\mathrm{P} 10$ & 80 & Moderate \\
\hline 11 & P11 & 79 & Moderate \\
\hline 12 & P12 & 77 & High \\
\hline 13 & P13 & 80 & Moderate \\
\hline 14 & $\mathrm{P} 14$ & 82 & Low \\
\hline 15 & $\mathrm{P} 15$ & 83 & Low \\
\hline 16 & P16 & 84 & Low \\
\hline 17 & P17 & 77 & High \\
\hline 18 & P18 & 82 & Low \\
\hline 19 & P19 & 79 & Moderate \\
\hline 20 & $\mathrm{P} 20$ & 85 & Low \\
\hline 21 & P21 & 84 & Low \\
\hline 22 & P22 & 79 & Moderate \\
\hline 23 & P23 & 79 & Moderate \\
\hline 24 & P24 & 79 & Moderate \\
\hline 25 & $\mathrm{P} 25$ & 85 & Low \\
\hline 26 & P26 & 76 & High \\
\hline 27 & P27 & 81 & Low \\
\hline 28 & P28 & 82 & Low \\
\hline 29 & P29 & 82 & Low \\
\hline 30 & P30 & 79 & Moderate \\
\hline 31 & P31 & 78 & Moderate \\
\hline 32 & P32 & 80 & Moderate \\
\hline 33 & P33 & 78 & Moderate \\
\hline 34 & P34 & 74 & High \\
\hline 35 & P35 & 80 & Moderate \\
\hline
\end{tabular}

Based on the data comparison in Table 4 above, it was discovered that 14 participants (40.0\%) who demonstrate the low speaking anxiety level (P2, P6, P8, P9, P14, P15, P16, P20, P21, P25, P27, P28, and P29) have the highest scores for speaking in the class, their respective speaking scores range from 81 to 85 . Meanwhile, 15 participants (42.9\%) who are at the moderate level (P1, P3, P5, P10, P11, P13, P19, P22, P23, P24, P30, P31, P32, $\mathrm{P} 33$, and $\mathrm{P} 35)$ have decent scores in the range of 78 to 80 . Lastly, 6 participants (17.1\%) who are at the high level of speaking anxiety (P4, P7, P12, P17, P26, and P34), in fact, have the lowest scores for speaking in the range of 74 to 77 .

\section{The Overall Results of Analysis}

Referring to the analysis of the three data sets, the overall findings are displayed in Table 5 below. The aim is to provide a clear presentation about the result of the levels of English-speaking anxiety of the participants in this study. 
Table 5. The Overall Results of Participants' English-Speaking Anxiety Levels

\begin{tabular}{|c|c|c|c|c|c|}
\hline No. & Participant & $\begin{array}{c}\text { Number of } \\
\text { Speaking } \\
\text { Anxiety Sign(s) }\end{array}$ & $\begin{array}{c}\text { FLSAS } \\
\text { Score }\end{array}$ & $\begin{array}{c}\text { Speaking } \\
\text { Performance } \\
\text { Score }\end{array}$ & $\begin{array}{l}\text { Level of } \\
\text { English- } \\
\text { speaking } \\
\text { Anxiety } \\
\end{array}$ \\
\hline 1. & P1 & $\begin{array}{l}2 \text { Signs } \\
\text { (Using speech } \\
\text { fillers; } \\
\text { Stuttering) }\end{array}$ & 63 & 79 & Moderate \\
\hline 2. & $\mathrm{P} 2$ & No Sign & 49 & 83 & Low \\
\hline 3. & P3 & $\begin{array}{l}3 \text { Signs } \\
\text { (Going blank; } \\
\text { Using speech } \\
\text { fillers; } \\
\text { Speaking too } \\
\text { fast) }\end{array}$ & 61 & 79 & Moderate \\
\hline 4. & P4 & $\begin{array}{l}\text { S Signs } \\
\text { (Using speech } \\
\text { fillers; } \\
\text { Making } \\
\text { grammatical } \\
\text { mistakes; } \\
\text { Speaking too } \\
\text { slow) }\end{array}$ & 72 & 76 & High \\
\hline 5. & P5 & $\begin{array}{l}2 \text { Signs } \\
\text { (Going blank; } \\
\text { Using speech } \\
\text { fillers) }\end{array}$ & 64 & 80 & Moderate \\
\hline 6. & P6 & No Sign & 48 & 84 & Low \\
\hline 7. & P7 & $\begin{array}{l}4 \text { Signs } \\
\text { (Going blank; } \\
\text { Using speech } \\
\text { fillers; } \\
\text { Making } \\
\text { grammatical } \\
\text { mistakes; } \\
\text { Making } \\
\text { unnecessary } \\
\text { body } \\
\text { movements) }\end{array}$ & 70 & 77 & High \\
\hline 8. & P8 & No Sign & 49 & 83 & Low \\
\hline 9. & P9 & No Sign & 33 & 84 & Low \\
\hline 10. & $\mathrm{P} 10$ & $\begin{array}{l}2 \text { Signs } \\
\text { (Using speech } \\
\text { fillers; Speaking } \\
\text { too fast) }\end{array}$ & 56 & 80 & Moderate \\
\hline 11. & P11 & $\begin{array}{l}2 \text { Signs } \\
\text { (Using speech } \\
\text { fillers; } \\
\text { Making } \\
\text { grammatical } \\
\text { mistakes) }\end{array}$ & 61 & 79 & Moderate \\
\hline
\end{tabular}




\begin{tabular}{|c|c|c|c|c|c|}
\hline 12. & P12 & $\begin{array}{l}4 \text { Signs } \\
\text { (Using speech } \\
\text { fillers; } \\
\text { Making } \\
\text { grammatical } \\
\text { mistakes; } \\
\text { Stuttering; } \\
\text { Making } \\
\text { unnecessary } \\
\text { body } \\
\text { movements) }\end{array}$ & 71 & 77 & High \\
\hline 13. & P13 & $\begin{array}{l}\text { 3 Signs } \\
\text { (Going blank; } \\
\text { Using speech } \\
\text { fillers; } \\
\text { Making } \\
\text { unnecessary } \\
\text { body } \\
\text { movements) }\end{array}$ & 54 & 80 & Moderate \\
\hline 14. & P14 & $\begin{array}{l}1 \text { Sign } \\
\text { (Making } \\
\text { grammatical } \\
\text { mistakes) }\end{array}$ & 47 & 82 & Low \\
\hline 15. & $\mathrm{P} 15$ & No Sign & 50 & 83 & Low \\
\hline 16. & P16 & No Sign & 34 & 84 & Low \\
\hline 17. & P17 & $\begin{array}{l}4 \text { Signs } \\
\text { (Using speech } \\
\text { fillers; } \\
\text { Making } \\
\text { grammatical } \\
\text { mistakes; } \\
\text { Stuttering; } \\
\text { Making } \\
\text { unnecessary } \\
\text { body } \\
\text { movements) }\end{array}$ & 69 & 77 & High \\
\hline 18. & P18 & $\begin{array}{l}\text { 1 Sign } \\
\text { (Using speech } \\
\text { fillers) }\end{array}$ & 35 & 82 & Low \\
\hline 19. & P19 & $\begin{array}{l}2 \text { Signs } \\
\text { (Going blank; } \\
\text { Using speech } \\
\text { fillers) }\end{array}$ & 63 & 79 & Moderate \\
\hline 20. & $\mathrm{P} 20$ & No Sign & 50 & 85 & Low \\
\hline 21. & $\mathrm{P} 21$ & No Sign & 18 & 84 & Low \\
\hline 22. & $\mathrm{P} 22$ & $\begin{array}{l}3 \text { Signs } \\
\text { (Going blank; } \\
\text { Using speech } \\
\text { fillers; } \\
\text { Speaking too } \\
\text { fast) }\end{array}$ & 53 & 79 & Moderate \\
\hline
\end{tabular}




\begin{tabular}{|c|c|c|c|c|c|}
\hline 23. & $\mathrm{P} 23$ & $\begin{array}{l}2 \text { Signs } \\
\text { (Using speech } \\
\text { fillers; } \\
\text { Making } \\
\text { grammatical } \\
\text { mistakes) } \\
\end{array}$ & 64 & 79 & Moderate \\
\hline 24. & P24 & $\begin{array}{l}2 \text { Signs } \\
\text { (Going blank; } \\
\text { Using speech } \\
\text { fillers) }\end{array}$ & 60 & 79 & Moderate \\
\hline 25. & $\mathrm{P} 25$ & No Sign & 30 & 85 & Low \\
\hline 26. & P26 & $\begin{array}{l}5 \text { Signs } \\
\text { (Going blank; } \\
\text { using speech } \\
\text { fillers; Making } \\
\text { unnecessary } \\
\text { body } \\
\text { movements; } \\
\text { Speaking too } \\
\text { fast; Stuttering) }\end{array}$ & 78 & 76 & High \\
\hline 27. & $\mathrm{P} 27$ & $\begin{array}{l}\text { 1 Sign } \\
\text { (Speaking too } \\
\text { fast) }\end{array}$ & 39 & 81 & Low \\
\hline 28. & $\mathrm{P} 28$ & $\begin{array}{l}\text { 1 Sign } \\
\text { (Making } \\
\text { grammatical } \\
\text { mistakes) }\end{array}$ & 32 & 82 & Low \\
\hline 29. & P29 & $\begin{array}{l}\text { Sign } \\
\text { (Making } \\
\text { grammatical } \\
\text { mistakes) } \\
\end{array}$ & 33 & 82 & Low \\
\hline 30. & P30 & $\begin{array}{l}2 \text { Signs } \\
\text { (Using speech } \\
\text { fillers; } \\
\text { Making } \\
\text { unnecessary } \\
\text { body } \\
\text { movements) }\end{array}$ & 64 & 79 & Moderate \\
\hline 31. & P31 & $\begin{array}{l}2 \text { Signs } \\
\text { (Using speech } \\
\text { fillers; } \\
\text { Stuttering) }\end{array}$ & 54 & 78 & Moderate \\
\hline 32. & P32 & $\begin{array}{l}3 \text { Signs } \\
\text { (Going blank; } \\
\text { Using speech } \\
\text { fillers; } \\
\text { Speaking too } \\
\text { fast) }\end{array}$ & 54 & 80 & Moderate \\
\hline 33. & P33 & $\begin{array}{l}2 \text { Signs } \\
\text { (Going blank; } \\
\text { Using speech } \\
\text { fillers) }\end{array}$ & 66 & 78 & Moderate \\
\hline
\end{tabular}




\begin{tabular}{|c|c|c|c|c|c|}
\hline 34. & P34 & $\begin{array}{l}5 \text { Signs } \\
\text { (Going blank; } \\
\text { using speech } \\
\text { fillers; Making } \\
\text { grammatical } \\
\text { mistakes; } \\
\text { Making } \\
\text { unnecessary } \\
\text { body } \\
\text { movements; } \\
\text { Speaking too } \\
\text { fast) }\end{array}$ & 84 & 74 & High \\
\hline 35. & P35 & $\begin{array}{l}2 \text { Signs } \\
\text { (Going blank; } \\
\text { Using speech } \\
\text { fillers) }\end{array}$ & 56 & 80 & Moderate \\
\hline \multicolumn{2}{|c|}{ Average $=$} & 2 Signs & 53.83 & 80,3 & $\begin{array}{l}\text { Moderate } \\
\text { Level }\end{array}$ \\
\hline
\end{tabular}

Based on the table above, it was discovered that the observation data were supported by the questionnaire data. Evidently, 14 participants (P2, P6, P8, P9, P14, P15, P16, P20, $\mathrm{P} 21, \mathrm{P} 25, \mathrm{P} 27, \mathrm{P} 28$, and $\mathrm{P} 29$ ) who had 0 to 1 sign of anxiety in their speaking performances perceive their speaking anxiety to be at a low category. Meanwhile, 15 participants (P1, P3, P5, P10, P11, P13, P19, P22, P23, P24, P30, P31, P32, P33, and P35) who demonstrated 2 to 3 signs of anxiety in their speaking performances perceive their speaking anxiety to be at a moderate category. Finally, 6 participants (P4, P7, P12, P17, P26, and P34) who showed 4 to 5 signs of anxiety in their speaking performances perceive their speaking anxiety to be at a high category. Furthermore, as supplementary evidence, the participants' speaking scores were compared with the data from observation and questionnaire. Based on the comparison, the speaking scores of the 14 participants with the low speaking anxiety are in the range of 81-85. Meanwhile, the speaking scores of the 15 participants with the moderate speaking anxiety are in the range of 78-80. Lastly, the speaking scores of the 6 participants with the high speaking anxiety are in the range of 74-77. On average, the participants generally experience moderate level of speaking anxiety. It was evident that the average number of speaking signs as observed by the researcher in their speaking performances is 2 . Added to that, the mean FLSAS score of participants is 53.83, where it falls into the range of 51-68 or known as the moderate level of self-perceived speaking anxiety.

\section{DISCUSSION}

Based on the results of analysis presented in the above section, the English-speaking anxiety levels of the participants can be categorized into three categories.

The first category is a low speaking anxiety level. There are 14 students (40.0\%) in this category. It was found that 9 of them did not show any sign of speaking anxiety, and 5 of them exhibited only 1 sign that yet appeared slightly. This indicates that they had the least speaking anxiety signs in their speaking performances. Additionally, their FLSAS scores are in the range of 18-50. Based on the adapted FLSAS score-interpretation, they are classified in the low speaking anxiety category, where it implies a slight feeling of apprehension in 
communication, negative evaluation, and test-anxiety. Correspondingly, their low level of speaking anxiety is found to have a facilitating effect on their speaking performances. It was found that they have the highest speaking scores in the class that range from 81 to 85 . The possible reason behind the low level of speaking anxiety experienced by 14 participants may be the awareness of the fact that being able to speak English is mandatory for English-major students. For this reason, they try to improve their speaking ability eagerly inside or outside their classroom; thus, they experience a low level of speaking anxiety.

The second category is a moderate speaking anxiety level. There are 15 participants (42.9\%) who are classified in this category. It was revealed that out of 15 participants, 11 participants seemed to show 2 signs, and 4 participants demonstrated 3 signs in their speaking performances. The 2 to 3 speaking anxiety signs signified that the participants are moderately anxious in speaking. Added to this, their FLSAS scores range from 51 to 68. According to the adapted FLSAS score-interpretation, they are categorized in the moderate speaking anxiety, where it means that the participants' feelings toward communication apprehension, fear of negative evaluation, and test-anxiety are fairly intense, but not remarkable. As supporting evidence, it was discovered that speaking scores of the participants with a moderate speaking anxiety level are in the range of 78-80. According to Dobson (2012:24), the possible reason behind the moderate level of speaking anxiety is the low self-confidence factor in the situation where students think their performance is judged, being compared, or very crucial, for instance speaking test or presentation, which manifests in emotional and physical tension.

The last category is a high speaking anxiety level. There are 6 participants (17.1\%) in this category. It was apparent that 4 of them displayed 4 speaking anxiety signs, and 2 of them showed 5 signs of speaking anxiety in their performances. Thus, they had the most signs of anxiety in their speaking performances compared to other groups. Added to this, their FLSAS scores are in the range of 69-79. According to the adapted FLSAS scoreinterpretation, they fall into the high speaking anxiety category, where it indicates a severe feelings of communication apprehension, fear of negative evaluation, and test anxiety. Moreover, it turned out that their speaking achievements are the lowest in the class with their scores ranging from 74 to 77. According to Horwitz et al. (as cited in Çağatay, 2015:2), the possible reason behind the high speaking anxiety level is the combination of severe apprehension in speaking as to being overwhelmed by a number of rules in speaking English, fear of speaking test, and fear of negative evaluation. As a result, highly anxious students are hesitant to speak, and making unnecessary body movements when they take a risk to perform a speech in front of the class.

After having explained the findings of each level of participants' speaking anxiety and their connection to existing theories, the average level of participants' speaking anxiety is discussed in the following paragraphs.

Overall, the average speaking anxiety level of participants is moderate. Evidently, the average number of speaking signs in their speaking performances is 2 . Added to that, the mean FLSAS score of participants is 53.83, where it falls into the range of moderate category of speaking anxiety. In other words, the participants' feelings toward speaking anxiety on the average are fairly intense, but not remarkable enough to harm their speaking 
performances. The result of this study is consistent with previous studies by Çagatay (2015), Tridinanti (2018), and Miskam \& Saidalvi (2019) which reported that the average level of EFL students' speaking anxiety is at the moderate level. In addition, their findings also corroborate this study's result in the way that speaking anxiety signs appeared at times, and impacted speaking fluency, but the overall speaking performances were not severely affected. However, a moderate level of English-speaking anxiety is still worrying since this level of anxiety can still be debilitative to the speaking skill development. That is because a fairly intense communication apprehension, fear of negative evaluation, and test-anxiety can be a boundary for the students to express their whole-thoughts through oral communication.

On the contrary, the result of this study is opposite to the findings by Öztürk \& Gürbüz (2014) and Debreli \& Demirkan (2016) who reported that the average level of students' speaking anxiety is low. In contrast to the present study, their studies found that the signs of anxiety that generally appeared in students' performances were slight and did not affect the performances. Other previous studies that also reported contradictory results are from Agudo (2013), Abrar et al. (2016), and Rumiyati \& Setfika (2018). By having an opposite result to the present study, their studies are in agreement that the average level of speaking anxiety is high, and they similarly share that the speaking anxiety signs that appeared were extremely debilitating to the students' performances. Moreover, the finding of the present study is also not in line with the one found by Debreli \& Demirkan (2016). Their study revealed that students with a higher speaking achievement surprisingly have a higher level of speaking anxiety. This is dissimilar to the finding in this study which discovered that students with a higher speaking score have a lower level of speaking anxiety, and students with a lower speaking score have a higher level of speaking anxiety. Nonetheless, this present study's finding is consistent with Krashen (as cited in Arena 2013:125) who states that a low speaking anxiety facilitates satisfactory speaking performance and contributes to potentially high academic achievements.

\section{CONCLUSION}

Based on the findings of this study, it can be concluded that 14 participants (40.0\%) fall into a low speaking anxiety level, 15 participants $(42.9 \%)$ are classified into a moderate speaking anxiety level, and 6 participants (17.1\%) are included in a high speaking anxiety level. It can be inferred from the discussion that participants with higher speaking anxiety level had more signs of anxiety in their English-speaking performances, and consequently, they have lower speaking achievements. In contrast, students with lower speaking anxiety level had fewer signs of speaking anxiety and as a result, they have higher speaking achievements. On average, the participants generally experience a moderate level of speaking anxiety. As evidenced, the average number of speaking anxiety signs of all participants is 2 , and their mean FLSAS score is 53.83. As 53.83 is included in the range of $51-68$ or known as moderate speaking anxiety category.

Given the fact that most students experience a moderate level of speaking anxiety, it is suggested that the lecturer should play a major role in creating comfortable classroom atmosphere and teaching strategies in order to encourage students to speak English confidently. Likewise, participants with moderate-to-high speaking anxiety levels should be 
active in finding ways to alleviate their speaking anxiety into low level in order to attain satisfactory achievement and improvement in spoken proficiency in the future.

\section{REFERENCES}

Abrar, M., Failasofah, F., Fajaryani, N., \& Masbirorotni, M. (2016). EFL Student Teachers' Speaking Anxiety: The Case in One English Teacher Education Program. Indonesian Journal of English Education-Vol. 3, No. 1, pp. 60-75. http://dx.doi.org/10.15408/ijee.v3i1.3619

Agudo, J. D. M. (2013). An Investigation into Spanish EFL Learners' Anxiety. RBLA, Belo Horizonte-Vol. 13, No. 3, pp. 829-851. https://doi.org/10.1590/S1984-63982013005000012

Arena, L.A. (2013). Language Proficiency: Defining, Teaching, and Testing. Berlin: Springer Science \& Business Media.

Burns, A. (2017). Research and the Teaching of Speaking in the Second Language Classroom. In Hinkel, E. (Ed), Vol III. New York: Routledge.

Çağatay, S. (2015). Examining EFL Students' Foreign Language Speaking Anxiety: The Case at a Turkish State University. Procedia - Social and Behavioral Sciences-Vol. 199, No. 1, pp. 648-656. https://www.sciencedirect.com/science/article/pii/S1877042815046133

Debreli, E., \& Demirkan, S. (2016). Sources and Levels of Foreign Language Speaking Anxiety of English as a Foreign Language University Students with regard to Language Proficiency and Gender. International Journal of English Language Education-Vol. 4, No. 1, pp. 49-62. http://dx.doi.org/10.5296/ijele.v4i1.8715

Dobson, C. (2012). Effects of Academic Anxiety on the Performance of Students with and without Learning Disabilities and How Students can Cope with Anxiety at School. Published MS dissertation, Northern Michigan University, USA.

Gałajda, D. (2017). Communicative Behavior of a Language Learner: Exploring Willingness to Communicate. New York: Springer.

Gass, S. M. (2013). Second Language Acquisition. New York: Routledge.

Gkonou, C., Daubney, M., \& Dewaele, J.M. (2017). New Insights into Language Anxiety: Theory, Research and Educational Implications. Bristol: Multilingual Matters.

Mahmoodzadeh, M. (2012). Investigating Foreign Language Speaking Anxiety within the EFL Learner's Interlanguage System: The Case of Iranian Learners. Journal of Language Teaching and Research-Vol. 3, No. 3, pp. 466-476.

Miskam, N. N., \& Saidalvi, A. (2019). Investigating English Language Speaking Anxiety among Malaysian Undergraduate Learners. Asian Social Science-Vol. 15, No. 1, pp. 1-7. https://doi.org/10.5539/ass.v15n1p1 
Öztürk, G., \& Gürbüz, N. (2014). Speaking Anxiety among Turkish EFL learners: The Case at a State University. Journal of Language and Linguistic Studies-Vol. 10, No. 1, pp. 1-17.

Rumiyati, R., \& Setfika, S. (2018). Anxiety of Speaking English in English Foreign Language. Journal of English Education, Literature and Linguistics-Vol. 1, No. 1, pp. 46-61.

https://ojs.stkippgri-lubuklinggau.ac.id/index.php/JEELL/article/view/37

Suleimenova, Z. (2013). Speaking Anxiety in a Foreign Language Classroom in Kazakhstan. Procedia-Social and Behavioral Sciences- Vol. 93, pp. 1860-1868.

Tridinanti, G. (2018). The Correlation between Speaking Anxiety, Self-Confidence, and Speaking Achievement of Undergraduate EFL Students of Private University in Palembang. International Journal of Education and Literacy-Vol. 6, No. 4, pp. 3539. http://dx.doi.org/10.7575/aiac.ijels.v.6n.4p.35 